\title{
EVALUASI KEBIJAKAN TENTANG KERJASAMA DI UNIVERSITAS X
}

\author{
Masnur Putra Halilintar, Trio Saputra \\ Universitas Lancang Kuning \\ e-mail: trio_saputra@unilak.ac.id
}

\begin{abstract}
The purpose of this research is to know how to evaluate policy about cooperation in $X$ presenting university and make ideal format of cooperation, research method using descriptive approach, research is arranged as inductive research is searching and collecting existing data field with aim to know factors, formelements, and a trait of phenomena. Data analysis through four stages of data processing, data presentation, and withdrawal. Result of research technique and technique. This is because there is no standard operating procedure (SOP). The attitude of the executor of the cooperation body has not been effective and the inter-organization must also coordinate in more depth.
\end{abstract}

Keywords: Cooperation, SOP, Policy, Law

Abstrak
Tujuan dari penelitian ini adalah untuk mengetahui bagaimana evaluasi kebijakan tentang kerjasama di universitas $x$ dan membuat format ideal kerjasama, metode penelitian ini menggunakan pendekatan deskriftif, penelitian disusun sebagai penelitian induktif yakni mencari dan mengumpulkan data yang ada dilapangan dengan tujuan untuk mengetahui faktor-faktor, unsur-unsur bentuk, dan suatu sifat dari fenomena. Analisis data melalui empat tahap yaitu tahap pengumpulan data, penyajian data, dan penarikan kesimpulan.Hasil penelitian menunjukkan kebijakan tentang kerjasama di universitas $x$ belum mempunyai aturan yang legal, serta standartdan tujuan kerjasama belum dipahami sepenuhnya oleh pimpinan dan komunikasi antar organisasi belum sepenuhnya lancar. Hal ini karena belum adanya standart oprasional prosedur (SOP). Sikap pelaksana badan kerjasama belum efektif selain itu antar organisasi juga harus berkoordinasi secara lebih mendalam terkait peraturan kerjasama.

Kata Kunci : Kerjasama, SOP, Kebijakan, Legal

\section{PENDAHULUAN}

Berdasarkan peraturan Menteri Pendidikan Dan Kebudayaan Republik Indonesia Nomor 14 tahun 2014 tentang Kerja Sama Perguruan Tinggi dijelaskan bahwa Kerja sama perguruan tinggi bertujuan meningkatkan efektivitas,efisiensi, produktivitas, kreativitas, inovasi, mutu, dan relevansi pelaksanaan Tridharma Perguruan Tinggi untuk meningkatkan daya saing bangsa. Perguruan tinggi melakukan kerja sama pada berbagai bidang baik bidang akademik dan/atau bidang non-akademik dengan perguruan tinggi lain, dunia usaha, atau pihak lain ,baik dalam negeri maupun luar negeri. Diharapkan melalui kerjasama akan memberikan manfaat bagi seluruh pihak. Sebuah kerjasama (co-operation) yang menggabungkan 2 sifat, yakni saling memberi atau bertukar sumberdaya dan sifat saling menguntungkan akan mengarah pada sebuah proses kolaborasi (Hardi, 2009) Kerjasama bidang akademik dapat dilakukan melalui penyelenggaraan pendidikan, penelitian, dan pengabdian kepada masyarakat, penjaminan mutu internal, program kembaran, gelar bersama, gelar ganda, pengalihan atau pemerolehan angka kredit atau satuan lain yang sejenis, penugasan dosen senior sebagai pembina pada perguruan tinggi yang membutuhkan 
pembinaan, pertukaran dosen dan/atau mahasiswa, pemanfaatan bersama berbagai sumber daya, pengembangan pusat kajian Indonesia dan budaya local, penerbitan berkala ilmiah, pemagangan, penyelenggaraan seminar bersama, dan hal lain yang dianggap perlu. Sedankan kerja sama bidang nonakademik dapat dilakukan melalui pendayagunaan asset, penggalangan dana, jasa dan royalti hak kekayaan intelektual; pengurangan tariff, koordinator kegiatan, pemberdayaan masyarakat dan bentuk lain yang dianggap perlu.

Sejak beberapa tahun terakhir, Universitas x sudah banyak mengelola kegiatan kerja sama secara melembaga yang dilakukan oleh para dosen di tingkat fakultas maupun universitas. Kerja sama tersebut tentu akan semakin meningkat, baik kuantitasnya maupun kualitasnya pada masa-masa mendatang. Hal ini sejalan dengan semakin terbukanya arus informasi dan meningkatnya kebutuhan di antara berbagai institusi.Salah satu kondisi yang menarik untuk dilihat adalah kerjasama yang telah dilakukan oleh Universitas x Beradasarkan data awal ditemukan lebih dari 30 MOU kerjasama yang telah dilakukan oleh Unilak, namun yang berlanjut hingga menjadi kegiatan tidak sampai 25\% Universitas x secara struktur telah memiliki bidang khusus yang menangani kerjasama yaitu Bidang kerjasama. Secara garis koordinasi,bidang ini bertanggung jawab langsung kepada Rektor. Namun, berbagai permasalahan terkait kerjasama masih ditemukan. Pertama, kerjasama di Universitas x belum memiliki skema/alur kerjasama. Alur kerja sama erat kaitannya dengan tahapan dan kewenangan terkait proses kerjasama. Sehingga masih ditemukan pihak-pihak yang menjalin kerjasama tanpa melibatkan unit yang bertanggungjawab langsung (kerjasama sistem by pass), masih banyak kerjasama yang tidak memiliki kajian awal/TOR. Selain itu, Kerjasama yang dilakukan dalam bentuk MoU banyak yang belum diturunkan dalam bentuk aplikatif / action. Ketiga, belum ada format kerjasama.

Berbagai permasalahan tersebut harus dicari solusi agar tidak memberikan dampak negatif seperti menurunnyakepercayaan pihak luar, tidak tersistematisnya alur/skema kerjasama, potensi konflik baik konflik eksternal maupun internal dan hilangnya manfaat kerjasama itu sendiri. Oleh karena itu solusi penting untuk mengidentifikasi permasalahan secara baik dan benar dengan melakukan evaluasi. Evaluasi menurut OECD, disebutkan bahwa Evaluasi merupakan proses menentukan nilai atau pentingnya suatu kegiatan,kebijakan, atau program (http://perencanaan.ipdn.ac.id/kajianperenc anaan/kajian-perencanaan /monitoring dan evaluasi, 2016).

Kondisi keilmuan saat ini, belum banyak ditemukan kejelasan kebijakan yang dapat digunakan sebagai referensi praktis untuk menyelenggarakan kerjasama dan membentuk unit kerjasama antar lembaga. Manfaat lain yang ingin diperoleh dari penyusunan model kerjasama,dengan memberikan alternatif pilihan baik bentuk kerjasama maupun model kelembagaannya pada perencanaan lembaga/institusi tekait.

\section{METODE}

Penelitian ini menggunakan pendekatan deskriptif. Penelitian ini disusun sebagai penelitian induktif yakni mencari dan mengumpulkan data yang ada di lapangan dengan tujuan untuk mengetahui faktorfaktor, unsur-unsur bentuk, dan suatu sifat dari fenomena di masyarakat. (Nazir, 1998: 51). Dalam penelitian ini peneliti menggunakan teknik purposive sampling dalam menentukan Informan penlitian. Selanjutnya peneliti berusaha secara cermat menentukan informan yang tepat.Untuk mencapai tujuan penelitian dan keakruratan data maka yang menjadi informan penelitian adalah pimpinan universitas, unit kerja yang berhubungan dengan tujuan penelitian,staf,dan beberapa pihak lain yang terlibat kerjasama dengan Universitas. 


\section{HASIL DAN PEMBAHASAN}

Bagian ini membahas mengenai sejauh mana Pelaksanaan kerja sama di Universitas x yang dilaksanakan di fakultas, badan, dan lembaga di Universitas x. Hasil wawancara menunjukkan bahwa, informan tidak tahu mengetahui adanya aturan kerjasama informan menjelaskan kerjasama yang dilakukan fakultas dengan melakukan tahapan studi banding, penjajakan dan melakukan Mou tanpa melalui bidang kerja sama Universitas x. Pernyataan wakil dekan I ini diperkuat oleh pernyataan kepala UPT perpustakaan universitas $\mathrm{x}$ selaku informan triangulasi. Berdasarkan hasil wawancara mendalam, kepala UPT perpustakaan menyatakan bahwa belum mengetahui aturan kerjasama dan tahapan kerjasama, proses kerjasama dilakukan langsung ke unit kerjasama dan penandatanganan Mou dilakukan rektor tanpa melalui bidang kerja sama.

\section{Standart dan tujuan kerjasama}

Bagian ini akan membahas mengenai standar dan tujuan kerjasama. Dalam tema ini, membahas seputar standar kerjasama dan tingkat perlu atau tidaknya diadakan peraturan ini. Berdasarkan hasil wawancara mendalam, diketahui bahwa pejabat fakultas tujuan dari bidang kerjasama dikarenakan dari fakultas dan unit masih bisa menjalankan secara langsung kerjasama. Di universitas sendiri tidak pernah menjelaskan secara detail apa standar dan tujuan dari bidang kerjasama. Melihat pernyataan informan, kenyataan di lapangan menunjukkan bahwa informan belum mengetahui dengan baik tujuan dari dibentuknya bidang kerjasma. Bukan hanya informan akan tetapi pembuat kebijakan (decision maker) juga perlu untuk mengetahui tujuan dari bidang ini sehingga, dimaksudkan agar bidang kerjasama akan berjalan maksimal karena semua pihak mengetahui tujuan dibentuknya bidang ini.

\section{Sumberdaya pelaksana kerjasama}

Bagian ini akan membahas mengenai sumberdaya pelaksana. Hal ini diketahui melalui wawancara mendalam dengan informan mengenai keaktifan fakultas, unit dan lembaga terkait dalam melakukan kerjasama. Sumberdaya adalah faktor penting untuk implementasi kebijakan tentang kerjasama agar efektif. Tanpa sumberdaya, kebijakan hanya tinggal kertas yang menjadi dokumen saja (Subarsono, 2013:91). Sebuah penelitian juga menunjukkan bahwa sumberdaya merupakan salah satu faktor penting yang mempengaruhi suksesnya pelaksanaan implementasi sebuah kebijakan (Tahir, 2010:20). Sumberdaya yang dimaksud adalah diantaranya sumberdaya manusia, sumberdaya finansial, dan sumberdaya sarana prasarana.Komunikasi antar organisasi Bagian ini membahas mengenai komunikasi yang terjadi diantara organisasi atau instansi terkait pelaksanaan kerjasama. Komunikasi yang kurang tepat antar organisasi juga dapat mengganggu pelaksanaan dikarenakan adanya ketidaksepemahaman antar organisasi. Kondisi tersebut menunjukkan masih kurangnya koordinasi antara unit. Terlihat dari unit mengenai kesepakatan tugas pokok dan fungsi mengenai peraturan kerjasama. Hal ini menunjukkan masih kurangnya komunikasi yang baik antar instansi sehingga menyebabkan kurang lancarnya koordinasi. Menurut informan, kurangnya komunikasi ini disebabkan oleh kesibukan masing-masing pekerjaan di instansi tempat mereka bernaung. Selain komunikasi antar pejabat pelaksana, pelaksanaan implementasi ini juga membutuhkan komunikasi yang baik antar pejabat pelaksana dan unit. Komunikasi dalam upaya penyampaian informasi mengenai kebijakan ini dapat dilakukan secara langsung maupun tidak langsung. Komunikasi secara langsung dilakukan dengan melaksanakan sosialisasi kepada pimpinan fakultas, unit atau lembaga di Universitas x, sedangkan komunikasi tidak langsung dilakukan melalui penyebaran informasi baik surat maupun peraturan (Tahir, 2010:13). Akan tetapi, semua hal tersebut terkendala dengan belum berjalannya komunikasi atau interaksi yang baik antar pejabat pelaksana serta sumberdaya finansial kebijakan yang berkurang setiap tahunnya. Kendala ini juga pada akhirnya menyebabkan komunikasi dengan target sasaran menjadi terhambat karena belum menemukan persamaan persepsi mengenai tupoksi pada instansi terkait. 


\section{Badan pelaksana kerjasama}

Bagian ini membahas tentang badan pelaksana kerjasama dalam pelaksanaan. Badan pelaksana ini terkait dengan instansi mana saja yang berperan dalam pelaksanaan kerjasama. Penentuan badan pelaksana merupakan bagian terpenting dalam pelaksanaan sebuah peraturan. Hal tersebut akan berpengaruh dalam pelaksanaan peraturan karena jika badan pelaksana telah ditetapkan maka instansi yang ditunjuk akan memiliki rasa tanggung jawab untuk melakukan pengawasan sesuai dengan peraturan yang diberikan. Bagian kali ini hanya ditanyakan khusus kepada informan dari instansi terkait dikarenakan informan utama secara keseluruhan sudah mengaku di awal kalau tidak mengetahui tentang peraturan kerjasama. Dalam melaksanakan kebijakan sesuai dengan standar dan tujuan maka diperlukan koordinasi antara pihak-pihak yang terlibat, sehingga akan meminimalkan kesalahan (Subarsono, 2013: 101). Kurangnya koordinasi antar badan pelaksana ini mengakibatkan pengawasan kerjasama di Universitas $\mathrm{x}$ hanya berjalan seadanya. Informan pun mengakui bahwa untuk melaksanakan kerjasama diperlukan tupoksi yang jelas dan kerjasama antar organisasi. Misalnya saja, dalam pelaksanaan monitoring dan pemberian sosialisasi kepada pimpinan fakultas, unit dan lembaga. Saat ini, pengawasan yang dilakukan hanya berupa pengecekan dengan bukti fisik surat kerjasama tidak ada sangsi khusus dalam pelanggaran kerjasama.

\section{Lingkungan pelaksana kerjasama}

Lingkungan yang berkaitan dengan pelaksanaan kerjasama Universitas $\mathrm{x}$ ini adalah terkait dengan kendala yang dihadapi di lapangan. Berdasarkan wawancara jelas menunjukkan bahwa kendala yang paling menghambat adalah instansi yang belum jelas tupoksi dan SOP sehingga hal ini membuat penerapan kerjasama ini terhambat karena masing-masing instansi merasa belum berkewajiban untuk menjalankan. Lingkungan kebijakan mencakup sumberdaya ekonomi lingkungan yang dapat mendukung keberhasilan implementasi kebijakan; sejauhmana kelompok-kelompok kepentingan memberikan dukungan bagi implementasi kebijakan; karakteristik para partisipan,yakni mendukung atau menolak; bagaimana sifat opini publik yang ada di lingkungan; dan apakah elite politik mendukung implementasi kebijakan (Subarsono, 2013: 101). Lingkungan yang dimaksud dalam kerjasama berkaitan dengan Mou dan Moa yang dilakukan oleh fakultas maupun badan. Lingkungan yang kondusif untuk berkembangnya kerjasama adalah lingkungan yang memahami pentingnya kerjasama. Lingkungan pelaksana meliputi mahasiswa, dosen dan pihak lainnya yang berkaitan dengan kerjasama. Kondisi saat ini masih menunjukkan apatis lingkungan terhadap kerjasama karena masih dinilai kerjasama yang ada sebelumnya belum memberikan dampak langsung kepada lingkungannya.

\section{Sikap pelaksana kerjasama}

Bagian ini menjelaskan tentang sikap pelaksana dalam pelaksanaan kerjasama. Sikap pelaksana ini tidak hanya dilihat melalui sikap para pimpinan akan tetapi, pada kondisi nyatanya merekalah yang akan menjadi subyek kebijakan ini. Sikap pelaksana dilihat melalui wawancara mendalam dengan informan tentang seberapa besar dukungan mereka untuk menjalankan kerjasama. Penilaian sikap pelaksana terdiri atas respons pelaksana terhadap kebijakan yang akan mempengaruhi kemauannya untuk melaksana kebijakan serta pemahamannya terhadap kebijakan itu sendiri (Subarsono, 2013:101).

Hasil penelitian menunjukkan bahwa pelaksanaan badan kerjasama belum efektif. Selain itu, antar organisasi juga harus berkoordinasi secara lebih mendalam terkait peraturan kerjasama. Koordinasi tersebut berguna untuk menghindari pelemparan tugas (dari lemabaga satu merasa bukan tugasnya melempar kepada lembaga yang lain, lembaga lain merasa bukan tugasnya juga melempar lagi kepada lembaga yang lain lagi, begitu seterusnya).

Rekomendasi Format SOP Kerjasama,MoU, dan berita Acara Berdasarkan hasil penelitian maka peneliti merekomendasikan format SOP Kerjasama, Mou dan Berita Acara. Format ini diperlukan sebagai bentuk panduan bagi unit/lembaga dalam melaksanakan kerjasama. 


\section{KESIMPULAN}

Berdasarkan hasil penelitian mengenai Evaluasi kebijakan tentang kerjasama di universitas x, maka dapat ditarik kesimpulan sebagai berikut:

1. kebijakan tentang kerjasama di universitas $\mathrm{x}$ tidak memiliki aturan yang legal, kerjasama saat ini hanya melalui fakultas atau unit tanpa melalui bidang kerjasama.

2. Standar dan tujuan kerjasama belum dipahami sepenuhnya oleh para pimpinan.

3. Sumber daya kebijakan dengan dibentuknya bidang kerjasama masih belum sepenuhnya terpenuhi.

4. Komunikasi antar organisasi belum sepenuhnya berjalan lancar. Hal ini didasarkan pada pernyataan pimpinan fakultas, unit dan lembaga yang ada di universitas $\mathrm{x}$ yang belum mengetahui mengenai tupoksi bidang kerjasama. Selain itu, komunikasi antara pejabat pelaksana dengan bidang kerjasama juga belum berjalan lancar karena belum adanya sosialisasi yang dilakukan untuk membahas peraturan terkait kerjasama, baik dalam bentuk komunikasi langsung maupun tidak langsung.

5. Badan pelaksana kebijakan ini juga belum berjalan dengan kuat. Hal ini dikarenakan belum adanya standar operasional (SOP).

6. Lingkungan kebijakan ini belum sepenuhnya mendukung. kendala yang paling menghambat adalah instansi yang belum jelas tupoksi dan SOP sehingga hal ini membuat penerapan kerjasama ini terhambat karena masing-masing instansi merasa belum berkewajiban untuk menjalankan.

7. sikap pelaksana badan kerjasama belum efektif. Selain itu, antar organisasi juga harus berkoordinasi secara lebih mendalam terkait peraturan kerjasama.

\section{DAFTAR PUSTAKA}

[1]. Cornago, N. "On the Normalization of Sub-state Diplomacy", The Hague Journals of Diplomacy 5 (Nov, 2009), pp 11-36

[2]. Dwidjowijoto, Riant N. (2007). Analisis Kebijakan. Cetakan Pertama. Jakarta: PT. Gramedia Elex Media Komputindo-Kelompok Gramedia

[3] Dunn, William. 2000. Pengantar Analisis Kebijakan Publik. Yogyakarta:Gajah Mada Universty Press.

[4] Hessel Nogi S.Tangkilisan.(2003) Kebijakan publik yang membumi: konsep, strategi \& kasus. Terjemahan.Kerjasama Lukman Offset\&Yayasan Pembaruan Administrasi Publik Indonesia.

[5] Moleong,J.Lexy. (2005). Metode Penelitian Kualitatif. Remaja Rosdakarya.Bandung.

[6] Saputra, T., \& Marlinda, P. (2017). Capaian Pelayanan Kesehatan Dasar Di Kota Pekanbaru. Jurnal Ilmu Sosial Mamangan, 5(2), 79-88.

[7] Wibawa,Samodra,dkk. 1994.Evaluasi Kebijakan Publik. Raja Grafindo Persada.Jakarta

[8] Winarno, Budi. (2007). Kebijakan Publik: Teori dan Proses.Yogyakarta:Media Pressindo. 